\title{
Perkebunan Tembakau dan Kapitalisasi Ekonomi Sumatera Timur 1863-1930
}

\author{
Allan Akbar \\ Pascasarjana Ilmu Sejarah Universitas Indonesia
}

\begin{abstract}
Abstrak
Daerah Sumatera Timur yang sebelumnya merupakan hutan belantara, dalam waktu singkat telah menjadi wilayah perkebunan paling menguntungkan di Sumatera. Perkembangan ini terjadi berkat keberhasilan budidaya tembakau di Sumatera Timur. Keuntungan yang besar dari perkebunan tembakau menarik minat para investor asing untuk menanamkan modalnya di Sumatera Timur. Selain mendatangkan kekayaan yang besar, perkebunan tembakau telah membawa beberapa dampak bagi perkembangan Sumatera Timur. Penelitian ini akan menyoroti bagaimana perkembangan perkebunan tembakau hingga mendatangkan kekayaan bagi Sumatera Timur serta dampak apa saja yang ditimbulkan akibat dari maraknya pembukaan perkebunan tersebut
\end{abstract}

Kata Kunci: Perkebunan, Tembakau, Penanaman Modal, Ekomomi, Sumatera Timur.

\section{A. Pendahuluan}

Selama menjelang akhir abad ke-19 Sumatera Timur telah menjadi lokasi salah satu usaha paling intensif dan paling berhasil perkebunan asing di dunia ketiga. (Stoler, 2005:2) $)^{1}$ Selama abad ini perkebunan menjadi aspek terpenting dalam perkembangan ekonomi di Indonesia pada masa kolonial. Sebelumnya, nama Sumatera Timur sebagai sebuah keresidenan di Hindia-Belanda pada awal abad ke19 mungkin tidak terlalu dikenal oleh masyarakat Eropa.

\footnotetext{
1 Ann Laura Stoler, Kapitalisme dan Konfrontasi di Sabuk Perkebunan Sumatera, 1870-1979, (Jakarta: Karsa, 2005), hlm. 2.
} 
Usaha perkebunan yang semula diadakan di Jawa, pada menjelang akhir abad ke-19 mulai meluas dan dikembangkan di luar pulau Jawa, khususnya Sumatera. Perluasan usaha perkebunan itu nampaknya sejalan dengan proses ekspansi dan pasifikasi kekuasaan kolonial Belanda di wilayah Nusantara dalam rangka menerapkan kebijakan politik "Pax Nederlandica" Belanda yang menginginkan seluruh wilayah kepulauan Indonesia berada di dalam kekuasaan Belanda.

Sementara itu wilayah perkebunan (cultuurgebeid) di Sumatera Timur, mengalami perkembangan yang pesat. Selain tanahnya yang cocok untuk ditanami, juga dikarenakan tanaman seperti: tembakau, karet, teh, kopi, dan kelapa sawit memiliki prospek yang sangat menguntungkan dalam pasaran dunia. Sehingga tidaklah mengherankan jika pemerintah kolonial Belanda begitu antusias dalam mendukung para pengusaha swasta untuk membuka perkebunan dan menanamkan modalnya di daerah Sumatera Timur. Walaupun memang usaha-usaha perkebunan juga berkembang di daerah-daerah lain seperti Kalimantan, Sulawesi, dan Sumatera Selatan; tetapi kegiatan utama dari perkebunan di luar Jawa adalah daerah Sumatera Timur.

Perkembangan pesat ekonomi Sumatera Timur tidak lepas terjadi setelah tembakau Deli dalam waktu singkat menjadi populer di pasar tembakau Eropa sebagai pembungkus cerutu terbaik di dunia. Maraknya pembukaan perkebunanperkebunan tembakau seketika mengubah lahan-lahan kosong di kawasan Pantai Timur Sumatera menjadi daerah paling sibuk dengan aktivitas perkebunan komoditas ekspor. Perubahan dari daerah yang sama sekali tidak produktif secara ekonomi di awal tahun 1800 menjadi daerah dengan lompatan ekonomi yang sangat luar biasa pada dekade kedua pertengahan abad ke-19 menjadikan daerah Sumatera Timur layak dijuluki sebagai "Si Kuda Hitam dari Sumatera". 
Fenomena perkembangan ekonomi Sumatera Timur yang masif tentu saja memberikan pengaruh terhadap kondisi sosial dan politik di Sumatera Timur. Bagaimana perubahan-perubahan yang terjadi dan apa saja dampak yang signifikan di wilayah tersebut akan menjadi fokus utama penulisan ini. Tujuan dari kajian ini adalah untuk menjelaskan perubahan ekonomi serta dampaknya yang terjadi di Sumatera Timur terutama sejak maraknya pembukaan perkebunan-perkebunan tembakau oleh para investor asing.

\section{B. Ekonomi Sumatera Timur Sebelum Dibukanya Perkebunan Tembakau}

Sebelum masuknya perkebunan di wilayah ini, Sumatera Timur merupakan sebuah wilayah dataran rendah yang ditumbuhi hutan belantara. Cakupan wilayah yang dikenal sebagai Sumatera Timur menjulur dari daratan pantai di wilayah timur pulau Sumatera hingga ke daratan berbukit-bukit mulai dari Kabupaten Aceh Timur, Langkat, Deli Serdang, Asahan, sampai dengan daerah Labuhan Batu, sepanjang $280 \mathrm{~km}$ dari barat laut ke tenggara. Lebar daratan di sebelah utara ratarata adalah $30 \mathrm{~km}$, dan lebar daratan di sebelah selatan kira-kira $100 \mathrm{~km}$. (Husny, $1978: 25)^{2}$

Saat itu Deli memiliki banyak tanah kosong, luas, dan tidak diolah. Penduduk Deli tinggal di kampung-kampung sederhana. Rumah-rumah mereka terbuat dari gubuk kayu, beratap rumbia dan nipah. Pakaian penduduknya kotor dan lusuh. Walaupun demikian Deli memiliki tanah yang subur, untuk itu hampir sebagian besar penduduknya mengandalkan bidang pertanian sebagai mata pencaharian pokok.

\footnotetext{
2 Tengku H.M. Lah Husny, Lintasan Sejarah Peradaban Sumatra Timur 1612-1950, (Jakarta: Depdikbud, 1978), hlm. 25.
} 
Penduduk di Sumatera Timur sampai pertengahan abad ke-18 terdiri atas berbagai kelompok etnis dengan pola budaya yang berbeda. Penduduk yang menempati wilayah Sumatera Timur di antaranya adalah suku Melayu, Batak, Jawa, Aceh, Minangkabau, Orang-orang Cina, Eropa, dan lain sebagainya. Di antara suku-suku tersebut orang-orang Melayu dan Batak dapat dikatakan merupakan penduduk asli Sumatera Timur, sedangkan suku-suku lainnya merupakan kelompok-kelompok pendatang. ${ }^{3}$

Orang Melayu menurut Lah Husny adalah penduduk suku bangsa Melayu yang berdiam di dataran rendah atau pantai Sumatera Timur dan daerah pantai lainnya yang dinamakan juga Melayu Pesisir. Mereka yang disebut orang Melayu Pesisir Sumatera Timur di Tanah Deli ini adalah turunan campuran antara orang Melayu yang ada di daerah tersebut dengan suku bangsa Melayu yang datang dari Johor, Melaka, Riau dan suku bangsa Aceh. ${ }^{4}$

Etnis yang mendiami Sumatera Timur berasal dari beberapa daerah, di antaranya adalah Melayu Langkat, Deli, Serdang, Asahan, dan Labuhan Batu. Mereka banyak mendiami daerah di sepanjang pantai timur Sumatera. Sementara etnis Batak yang berada di daerah tersebut berasal dari wilayah pedalaman seperti Batak Karo dan Simalungun pada umumnya mendiami daerah di perbukitan di sebelah barat Sumatera Timur. Masyarakat tradisional Batak Simalungun secara politik dapat dibagi menjadi tujuh kerajaan kecil yaitu Siantar, Tanah Jawa, Panei, Dolok, Raja Panai, dan Silimaluta. Sistem kekerabatan orang-orang Batak Simalungun sama dengan kelompok-kelompok Batak lainnya dengan penekanan pada marga.

\footnotetext{
${ }^{3}$ Usman Pelly, Rata. R, dan Soenyata Kartadarmadja. Sejarah Sosial Daerah Sumatra Utara Kotamadya Medan. (Jakarta: Depdikbud, 1984), hlm. 2.

${ }^{4}$ Tengku H.M. Lah Husny, Op.Cit., hlm. 182.
} 
Dalam segi administrasi kolonial, Sumatera Timur merupakan sebuah keresidenan yang terdiri dari empat afdeeling, yakni Langkat, Deli dan Serdang, Asahan, Simalungun dan Karo yang masing-masing dipimpin oleh Asisten Residen. Keempat Asisten residen tersebut tunduk pada kekuasaan Residen. Sebelumnya, Keresidenan Sumatera Timur beribukota di Bengkalis, namun pada 1887 ibukota Keresidenan dipindahkan ke Medan terkait dengan perkembangan perkebunan yang berada di Sumatera Timur.

Selanjutnya, wilayah afdeeling terbagi ke dalam onder-afdeeling yang masing-masing dikepalai oleh seorang kontrolir. Wilayah onder-afdeeling dibagi lagi atas distrik-distrik di bawah kuasa ajudan distrik atau demang. Wilayah pemerintahan terendah disebut dengan onder-distrik atau negeri yang diperintah oleh kepala negeri. Mulai dari daerah distrik hingga jaluran yang berada di bawahnya, pemerintah Belanda menempatkan tenaga-tenaga pribumi sebagai kepala pemerintahan atau dikenal sebagai Inlandse Bestuur Ambtenaren (pegawai pemerintah pribumi). Sementara untuk jabatan kontrolir ke atas dipegang oleh orang-orang Belanda atau Europese Bestuur Ambtenaren (pegawai pemerintah Eropa). ${ }^{5}$

Sebelum pengusaha-pengusaha Barat datang untuk membuka lahan perkebunan, tanah vulkanik di sekitar Sumatera Timur yang subur telah dimanfaatkan oleh masyarakat di daerah sekitarnya, yaitu Batak Karo dan Melayu untuk menanam padi, cabai, dan tembakau secara berselang-seling. ${ }^{6}$ Sebagian besar penduduknya bermata pencaharian sebagai petani yang dilakukan secara berhuma, yaitu bercocok tanam dengan cara berladang di hutan-hutan. Petani-petani ladang telah melakukan pembukaan dan pembakaran hutan pada musim kering yang akan digunakan menanam umbi-umbian, sayur-mayur, tebu, dan pisang. Pada musim

\footnotetext{
${ }^{5}$ Usman Pelly, Rata. R, dan Soenyata Kartadarmadja, Op. Cit., hlm. 8.

${ }^{6}$ Anthony Reid (ed), Sumatera Tempo Doeloe: Dari Marco Polo sampai Tan Malaka, Jakarta:

Komunitas Bambu, 2010, hlm. 300.
} 
hujan berikutnya, lahan tersebut akan digunakan untuk menanam padi. Setelah penduduk mengenal tanaman lada, mereka memadukannya dengan sistem pertanian tradisional yaitu menanam lada secara berselang-seling di antara tanaman ubi-ubian dan padi.

Kegiatan ekonomi lainnya yang dilakukan oleh masyarakat Sumatera Timur sebelum kedatangan bangsa asing yaitu mereka telah melakukan usaha eksporimpor secara tradisional untuk memenuhi kebutuhan mereka. Lah Husny dalam tulisannya mengatakan bahwa perdagangan di Sumatera Timur khususnya wilayah Deli bersifat terbuka; penduduk menanam selain untuk keperluan sendiri, juga untuk perdagangan, bukan saja untuk dalam negeri, juga untuk luar negeri. Penduduk Sumatera Timur pada 1862 saat itu telah mengekspor bahan-bahan seperti: lada, beras, emas dari Bahorok, ikan kering, kacu (gambir), berbagai jenis minyak, keris lurus bermata dua belah, gading, sumbu badak, tembakau, kapur barus, hasil hutan, dan biji timah. Sedangkan barang-barang yang diimpor adalah tekstil kasar dan halus, candu, mesiu senapan, barang pecah belah dan barangbarang kelontong. Candu, mesiu dan senapan disalurkan ke pedalaman di tanah Karo. $^{7}$

Inggris merupakan bangsa Eropa pertama yang memiliki perhatian yang sungguh-sungguh terhadap kawasan pantai Timur Sumatera sebelum Belanda. Produksi lada dari kawasan Sumatera Timur menjadi sumber barang impor yang sangat penting. Begitu juga dengan barang-barang ekspor Penang yang menjadikan kawasan pantai Timur Sumatera sebagai pasar yang strategis. Keseriusan Inggris dalam menjajaki kawasan Pantai Timur Sumatera tersebut terlihat dengan mengirimkan John Anderson pada bulan Desember 1822 hingga April 1823 untuk menyelidiki dan menghimpun berbagai informasi tentang kawasan Pantai Timur Sumatera. Hasil perjalanannya tersebut ia tuliskan menjadi sebuah buku yang

\footnotetext{
${ }^{7}$ Tengku H.M. Lah Husny, Op.Cit., hlm. 132.
} 
sangat terkenal yakni "Mission To The East Coast of Sumatra" (Misi Perjalanan ke Pantai Timur Sumatra). ${ }^{8}$

Mengenai budidaya tembakau oleh masyarakat Sumatera Timur, dalam laporan perjalanannya itu, John Anderson melihat bahwa penanaman tembakau telah dilakukan oleh penduduk Sumatera Timur, namun hanya dalam skala kecil. Menurutnya, perdagangan yang dilakukan oleh penduduk Sumatera Timur, bukan lah merupakan perdagangan untuk mencari keuntungan yang sebesar-besarnya, tetapi hanya bersifat subsisten untuk mencukupi kebutuhan hidup sehari-hari.

Penanaman tembakau secara kecil-kecilan ini dilakukan oleh orang-orang Melayu dan Batak dengan cara yang sangat sederhana, yaitu dengan cara menyebarkan bibit di dalam kebun yang kecil. Dan setelah 20 hari baru dipindahkan ke kebun yang lebih luas, lalu kemudian baru ditanam dengan jarak kira-kira dua meter setiap baris. Setelah berumur dua bulan daunnya dikurangi agar pertumbuhannya menjadi lebih baik. Lalu setelah batangnya besar, penduduk mengambil 1-2 helai daun setiap saat yang menurut mereka daunnya hampir masak. Daun-daun ini kemudian dijemur selama empat hari, setelah itu baru dimasukkan ke dalam keranjang-keranjang kecil dan dijual. ${ }^{9}$

\section{Perkebunan Tembakau Sebagai Pusat Ekonomi Sumatera Timur}

Wilayah Sumatera Timur sebelumnya didominasi oleh hutan belantara, namun dalam beberapa dekade, terbukti wilayah Sumatera Timur berubah menjadi salah satu daerah penghasil komoditi ekspor tembakau terpenting di Hindia Belanda. Hal

\footnotetext{
${ }^{8}$ John Anderson, Mission to the East Coast of Sumatra in 1823, Oxford in Asia Historical Reprints, Kuala Lumpur: Oxford University Press, 1971.

${ }^{9}$ Ibid., hlm. 280.
} 
tersebut juga didukung oleh adanya Selat Malaka sebagai jalur ekonomi yang strategis menghubungkan Asia-Eropa. Daerah-daerah yang berada di sepanjang Pesisir Pantai Sumatera dan Semenanjung Malaya menjadi incaran para pengusaha Eropa untuk mengembangkan tanaman komoditas yang tengah laku di pasaran dunia.

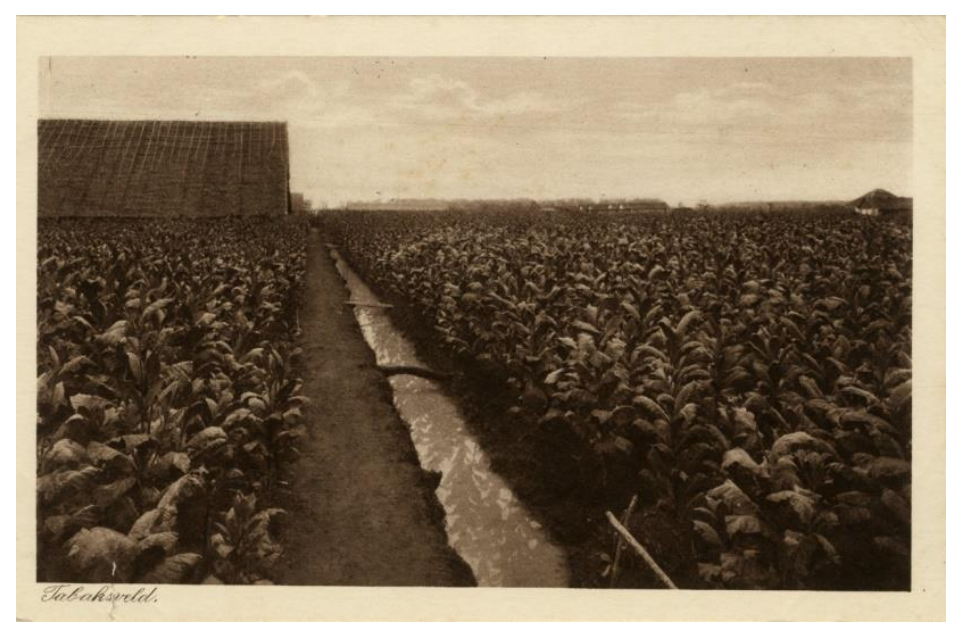

\section{Gambar 1: Perkebunan tembakau di Deli, Sumatera Timur (Sumber: KITLV)}

Selain itu mutu tanah yang berada di Sumatera Timur memiliki prospek untuk penanaman tembakau yang bernilai tinggi. Daerah Sumatera Timur, terutama Deli, baik di dataran rendah maupun di bukit-bukit, memiliki kondisi tanah yang sangat subur. Kesuburan ini dipengaruhi oleh endapan lumpur yang dikeluarkan dari letusan gunung berapi dari Bukit Barisan. Daerah Deli tidak pernah mengalami musim kering yang terlalu panjang dan juga tidak pernah mengenal musim hujan yang terlalu panjang. Musim hujan di Deli dimulai pada bulan Agustus dan berakhir pada bulan Januari. Sementara itu di musim kemarau masih ada juga curah 
hujan yang turun. ${ }^{10}$ Kondisi ini yang menyebabkan tanah di Deli menjadi subur dan sangat cocok untuk usaha perkebunan. Para pengusaha perkebunan sangat menaruh perhatian kepada mutu tanah dalam mempertimbangkan lahan untuk dikembangkan. Selama bertahun-tahun pengusaha-pengusaha perkebunan membedakan mutu tanah di Sumatera Timur, untuk menentukan lahan mana yang cocok ditanami tembakau sehingga dapat menghasilkan tembakau yang bermutu tinggi.

Budidaya tembakau dalam skala besar untuk pertama kalinya dilakukan pada 1863 oleh seorang saudagar Arab bernama Syaid Abdullah Ibn Umar Bilsagih. Namun karena kekurangan modal, ia mengajak saudagar-saudagar Belanda untuk membeli tanah kemudian menanami dengan tembakau di daerah Deli. Ia yakin apabila terdapat saudagar yang menanamkan modalnya di Deli, maka saudagar itu akan mengapatkan keuntungan yang besar dan usahanya akan maju. Untuk itu ia datang ke Jawa dengan tujuan menemui beberapa pedagang tembakau Belanda. Di hadapan pedagang-pedagang tembakau ini Sayid mempromosikan hasil bumi dari Deli yang di antaranya adalah lada dan tembakau dengan kualitas terbaik. Ia berkata bahwa Deli menghasilkan ekspor lada dan tembakau sebanyak 30.000 pikul pertahun dan tanah untuk bertanam disediakan oleh Sultan Deli. ${ }^{11}$

Berita tersebut terdengar ke seorang Belanda bernama Jacobus Nienhuys datang ke wilayah Deli atas usulan Sayid Abdullah ketika ia berkunjung ke Jawa pada 1863. Kemudian diutuslah Nienhuys oleh Firma van Leeuwen en Maintz \& Co selaku agen dari pembeli tembakau van den Arend untuk berangkat ke Deli.

\footnotetext{
${ }^{10}$ J. Paulus, J. Encyclopedie van Nederlandsch Indie. Leiden: EJ Brill, 1917), hlm. 578.

${ }^{11}$ Tengku Lukman Sinar, "Sejarah Perkebunan Sumatera Timur Abad ke-19 dan Dampak SosialEkonominya," Makalah Musyawarah Kerja Nasional Sejarah XII, Medan, 12-15 Juli 1994, hlm. 12 .
} 
Dengan menggunakan sebuah kapal carteran, ia tiba di Kuala Deli pada Juli $1863{ }^{12}$ Di Deli, Nienhuys datang menemui Sultan Deli untuk mengutarakan keinginannya membuka perkebunan tembakau di tanah Deli.

Saat itu Sultan langsung menyetujui usulan tersebut dan memberikan sejumlah tanah kepada Nienhuys. Pada 1864 Sultan Deli memberikan Nienhuys tanah sebanyak yang dia inginkan tanpa meminta uang sewa untuk ditanami tembakau. Nienhuys memperoleh tanah seluas 4000 bau. ${ }^{13}$ Nienhuys yang telah berpengalaman banyak dalam urusan menanam tembakau mulai melakukan percobaan penanaman tembakau di Kampung Martubung. Kondisi tanah dan iklim di Deli menurutnya sangat cocok untuk penanaman tembakau. Nienhuys kemudian memutuskan untuk menanam tembakau secara mandiri setelah mendapatkan konsesi dari Sultan Deli. ${ }^{14}$ Dalam konsesi itu Sultan juga menghendaki agar penduduk dari tiap-tiap wilayah yang tanahnya ditanami tembakau masih diizinkan untuk menanam padi setelah panen tembakau. ${ }^{15}$

\footnotetext{
${ }^{12}$ Mohammad Said, Suatu Zaman Gelap di Deli: Koeli Kontrak Tempo Doeloe dengan Derita dan Kemarahannya, (Medan: Waspada, 1977), hlm. 7.

${ }_{13}^{13}$ Satu bau setara dengan 7.096 meter persegi.

14 Thee Kian Wie, Plantation Agriculture and Export Growth: an Economic History of East Sumatra 1863-1942, (Jakarta: Lembaga Ekonomi dan Kemasyarakatan Nasional, 1977), hlm. 4.

${ }^{15}$ Dada Meuraxa, Sejarah Kebudayaan Suku-suku di Sumatera Utara, (Medan: Penerbit Sastrawan), hlm. 183.
} 


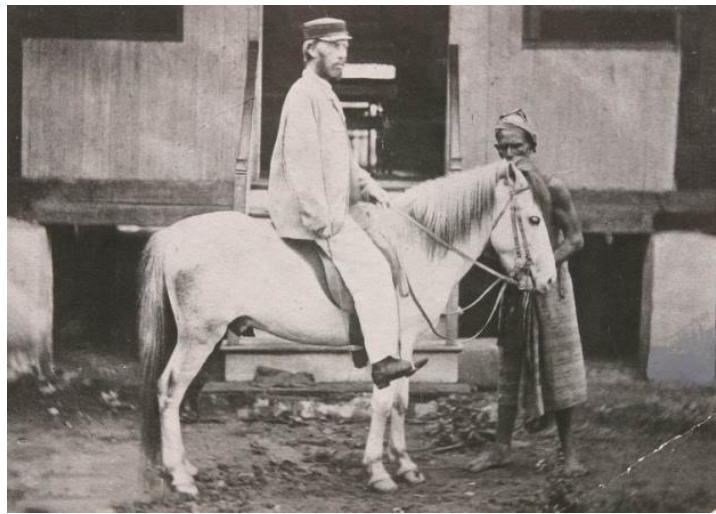

\section{Gambar 2: J. Nienhuys, pelopor penanaman tembakau di Sumatera Timur} (Sumber: KITLV)

Pemberian konsesi tanah merupakan sumber pemasukan yang penting bagi elite pribumi yang kadang-kadang para pejabat rendahan pun meminta imbalan atas kerja sama itu. Mula-mula pengusaha perkebunan mendatangi orang yang paling berpengaruh di wilayah itu seperti pejabat-pejabat kesultanan untuk meminta bantuan menjadi perantara dalam berhubungan dengan Sultan. Dalam hal ini para pengusaha perkebunan memberi uang pelicin dengan janji uang akan ditambah apabila kontrak tanah telah diperoleh. Setelah ada kesepakatan antara pengusaha perkebunan dan para pejabat kesultanan barulah pengusaha perkebunan membuat janji bertemi dengan Sultan.

Pembukaan perkebunan dimungkinkan apabila Sultan memberikan hak konsesi pengusahaan tanah atas kesepakatan. Akan tetapi pada kenyataannya, pembukaan perkebunan itu hanya melibatkan pengusaha perkebunan dan pihak Sultan, tanpa musyawarah dengan para pemuka masyarakat terutama kepala kampung di wilayah yang akan dijadikan perkebunan. Konsesi ini mengabaikan kedudukan dan hak-hak anggota masyarakat sebagai pemilik tanah ulayat, khususnya tanah-tanah yang bukan milik Sultan. Hal ini dilakukan karena menurut 
pendapat Sultan, bahwa seluruh tanah-tanah tersebut adalah milik Sultan, dan Sultan berhak memberikan tanah-tanah itu kepada siapa saja yang dianggapnya mampu memberikan sebagian hasilnya kepada Sultan. ${ }^{16}$

Berkat kualitas tembakau terbaik yang dimiliki keresidenan ini, dalam jangka waktu sepuluh tahun, Keresidenan Sumatera Timur menjadi terkenal di dunia sebagai penghasil ekspor 1/3 dari total ekspor yang dilakukan di seluruh Hindia Belanda. Menurut Pelzer pada periode menjelang 1920-an, perkebunan di Sumatera Timur telah mencapai luas yang mencengangkan. Mulai dari pusatnya di dekat Medan, perkebunan itu terhampar dalam rangkaian yang tak terputus-putus sepanjang 100 kilometer jaraknya ke arah timur-laut berbatasan dengan Aceh; kemudian 100 kilometer lagi jauhnya ke arah selatan ke bukit-bukit di balik kota Pematang Siantar; serta lebih dari 200 kolimeter ke arah tenggara ke dataran tinggi di sekitar Prapat, di daerah Asahan. ${ }^{17}$

Konsekuensi dari perkembangan perkebunan yang masif adalah kebutuhan yang besar tenaga kerja untuk mengolah perkebunan tersebut. Tenaga yang dipekerjakan untuk mengolah perkebunan adalah para buruh. Para buruh ini merupakan faktor penting yang turut berperan dalam ekspansi ekonomi di sektor perkebunan di Sumatera Timur. Berhasil atau tidaknya suatu perkebunan, amat dipengaruhi oleh faktor buruh dalam pengelolaannya.

Untuk itu, para pengusaha perkebunan berusaha untuk mendatangkan tenaga kerja dari luar daerah Deli, antara lain tenaga kerja dari Cina dan Jawa. Tatkala Nienhuys mendirikan Deli Maatschappij dan mulai mendapatkan keuntungan yang besar dari hasil berjualan tembakau, maka kebutuhan akan tenaga kerja menjadi semakin besar, terutama sekali ditujukan untuk ekspansi areal

\footnotetext{
${ }^{16}$ Lah Husny, Op.Cit., hlm. 91.

${ }^{17}$ Karl J. Pelzer, Op.Cit., hlm. 31-36.
} 
perkebunan tersebut. Atas usul T.J. Cremer, kebutuhan awal akan tenaga kerja kuli ini diatasi dengan mendatangkan tenaga kerja Cina yang bermukim di Penang. Hal ini didasarkan atas anggapan bahwa pekerja kuli Cina lebih giat dan tekun. ${ }^{18}$

Pengadaan tenaga kerja yang berasal dari luar Sumatera Timur dilakukan karena masyarakat lokal tidak bersedia untuk bekerja di perkebunan. Mereka tidak tertarik untuk menjadi buruh karena mereka telah mempunyai sumber kehidupan dari tanah-tanah yang mereka miliki. Selain itu juga, para pengusaha perkebunan lebih senang untuk mendatangkan buruh asal Cina -yang didatangkan via Penang dan Singapura - serta buruh dari Jawa ketimbang tenaga kerja yang berasal dari penduduk sekitar. Mereka menggambarkan bahwa penduduk lokal - Batak dan Melayu - memiliki sifat pemalas. Oleh karena sifat pemalas ini yang membuat buruh Cina dan Jawa lebih digemari untuk dipekerjakan daripada penduduk sekitar.

Buruh yang didatangkan ke perkebunan-perkebunan di Sumatera Timur ini diikat dengan sistem kontrak kerja selama tiga tahun. Biaya transportasi dan tempat tinggal ditanggung oleh penguasaha perkebunan. Setelah masa kontrak selesai, sang buruh boleh kembali ke daerah asalnya atas biaya sang majikan. Buruh-buruh tersebut diperoleh melalui agen-agen perusaha perkebunan di daerah asal mereka. Pada awalnya, buruh Cina diperoleh melalui agen-agen yang terikat dalam sistem kongsi di Semenanjung Malaya dan Singapura. Lalu pada perkembangannya, buruh-buruh Cina diperoleh melalui agen-agen Deli Planters Vereeniging (Perkumpulan Pengusaha Perkebunan Deli) di Jawa dengan sebutan werek. Dalam mencari calon buruh yang mau dilakukan dengan berbagai cara, tidak jarang para agen ini melakukan perekrutan dengan cara membujuk dan menipu calon buruh yang diincarnya. ${ }^{19}$

\footnotetext{
${ }^{18}$ Anthony Reid, Op.Cit., hlm. 200.

${ }^{19}$ Sjafri Sairin, "Kebijakan Perburuhan di Perkebunan Sumatera Timur Pada Masa Kolonial", Jurnal Antropologi Indonesia, No. 52, Tahun 1997, hlm. 55
} 
Buruh-buruh yang telah berhasil didatangkan itu harus membuat ikatan kerja dengan perkebunan, atau yang biasa disebut kontrak. Sistem kontrak inilah yang menjamin buruh-buruh itu tidak melarikan diri sebelum kontrak kerja mereka berakhir. Apabila mereka melarikan diri sebelum kontraknya habis, tentu saja pihak pengusaha akan mengalami kerugian besar. Pada 1880, suatu peraturan dibuat oleh pemerintah kolonial Hindia belanda untuk memberikan jaminan kepada penguasa bahwa buruh-buruh mereka tidak akan kabur. Peratutan ini dikenal dengan nama Koeli Ordonantie. Di dalam ketentuan itu di antaranya disebutkan bahwa siapa pun yang berusaha melarikan diri akan ditangkap polisi dan akan dibawa kembali ke perkebunan. Apabila melawan, mereka akan diangkut secara paksa dan akan mendapat berbagai hukuman, dalam contoh kerja paksa atau perpanjangan masa kontrak sepihak. ${ }^{20}$

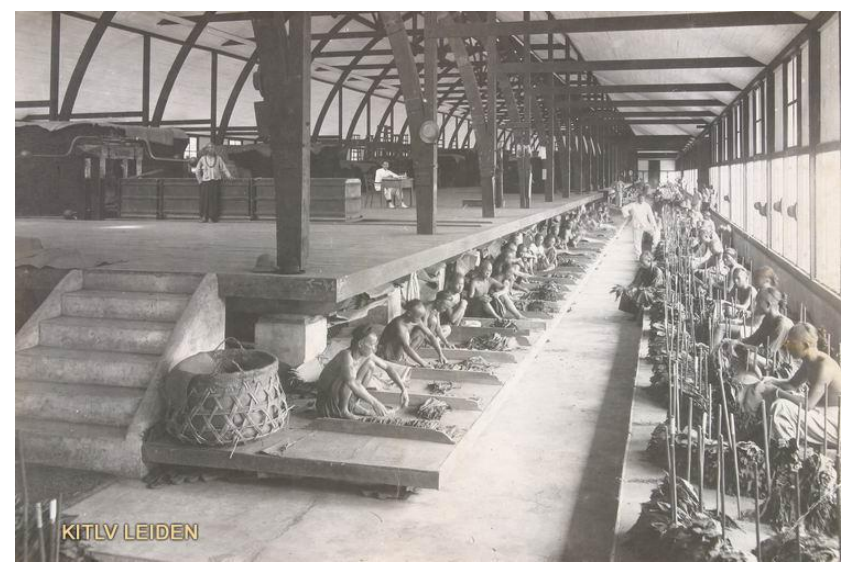

\section{Gambar 3: Para buruh perkebunan tembakau sedang mengolah tembakau (Sumber: KITLV)}

Sejak 1889, perusahaan-perusahaan perkebunan tembakau di Deli memasukkan sekitar 7.000 orang pekerja pertahun, dan berdasarkan kontrak kerja

${ }^{20}$ Cecil Rothe, Arbeid in de Landbouw: De Landbouw in de Indische Archipel, Vol. I, (Den Haag: 1949), hlm. 318. 
yang dibuat, sampai tahun 1930 jumlah kuli-kuli Cina telah berjumlah sekira setengah juta jiwa. ${ }^{21}$ Jumlah yang banyak ini dimungkinkan karena menurut para pengusaha perkebunan, buruh Cina merupakan tenaga kerja terbaik untuk menghasilkan tembakau kualitas tinggi, sehingga akan mendatangkan keuntungan yang lebih besar bagi para pengusaha.

Kedatangan buruh Cina di Sumatera Timur seperti membawa berkah terselubung bagi para pengusaha kebun. Bukan saja karena mereka pekerja yang cekatan, namun juga hemat. Ketika mereka berhenti sebagai seorang "kuli kebon", mereka menyewa sebagian tanah kosong di perkebunan untuk menanam sayuran dan memelihara babi yang diperlukan oleh orang-orang Eropa. Sementara sebagian lagi dari mereka membuka toko-toko kelontong untuk keperluan sehari-hari buruhburuh yang lain. Dari usahanya itu, perlahan-lahan ekonomi mereka mulai meningkat. Bagi mereka yang ekonominya telah meningkat, mereka lalu meminjam kredit dari perhimpunan mereka yang disebut "Gihin". Dari kredit tersebut mereka lalu membuka toko besar di kota dan menjadi agen impor barangbarang asing untuk masuk ke Sumatera Timur. ${ }^{22}$

Selain buruh asal Cina, para pengusaha perkebunan juga mendatangkan buruh asal Jawa. Pengadaan buruh asal Jawa ini dengan alasan pekerja-pekerja dari Jawa dianggap rajin dan tahan bekerja. Para pengusaha perkebunan tembakau Sumatera Timur sudah mengetahui bahwa para pekerja Jawa adalah pekerjapekerja yang memiliki keterampilan dalam bidang pertanian yang cukup tinggi sehingga mereka mudah menyesuaikan diri dengan kerja di perkebunan.

\footnotetext{
${ }^{21}$ Anthony Reid, Sumatera: Revolusi dan Elite Tradisional. Jakarta: Komunitas Bambu, 2012), hlm. 80.
}

${ }^{22}$ Tengku Lukman Sinar, Op.Cit., hlm. 11-12. 
Tabel Jumlah Buruh Cina dan Jawa di Sumatera Timur 1883-1930

\begin{tabular}{|l|l|l|l|}
\hline \multicolumn{1}{|c|}{ Tahun } & \multicolumn{1}{|c|}{ Buruh Cina } & \multicolumn{1}{|c|}{ Buruh Jawa } & \multicolumn{1}{|c|}{ Jumlah } \\
\hline 1883 & 21.136 & 1.711 & 22.874 \\
\hline 1893 & 41.700 & 18.000 & 59.700 \\
\hline 1898 & 50.846 & 22.256 & 73.102 \\
\hline 1906 & 53.105 & 33.802 & 86.907 \\
\hline 1913 & 53.617 & 118.517 & 172.134 \\
\hline 1920 & 27.715 & 209.459 & 237.174 \\
\hline 1930 & 26.037 & 234.554 & 260.591 \\
\hline
\end{tabular}

Sumber: Thee Kian Wie, Plantation Agricultural and Export Growth an Economic Histoty of East Sumatra, 1863-1942 (Jakarta: Lembaga Ekonomi dan Kemasyarakatan Nasional-LIPI, 1977), hlm. 39.

Dari tabel di atas terlihat jumlah tenaga kerja yang ada di perkebunan tembakau di Sumatera Timur pada periode 1883-1930. Pada mulanya buruh Cina dianggap kuli yang ulet bekerja dan mudah didapat di Semenanjung Malaka, serta ongkos mendatangkannya murah. Namun dengan banyaknya buruh Jawa yang ada di perkebunan tembakau dapat dilihat bahwa buruh Jawa juga merupakan tenaga kerja yang dapat diandalkan sama seperti buruh Cina. Hal ini dapat dilihat bahwa pada 1883 jumlah buruh Cina sebesar 21.136 orang sedangkan buruh Jawa hanya sebanyak 1.711. Begitu juga sepuluh tahun kemudian, yakni pada 1893, buruh Cina bertambah hampir dua kali lipat, tetapi buruh Jawa berjumlah 18.000. Walaupun hanya berjumlah 18.000 orang, tetapi kenaikannya secara presentase jauh melebihi 
kenaikan buruh Cina yang mencapai 97,3\%, sedangkan kenaikan jumlah buruh Jawa mencapai angka yang fantastis, yaitu hingga sepuluh kali lipat.

\section{Kapitalisasi Ekonomi Sumatera Timur}

Pada pertengahan abad ke-19, pemerintah kolonial Hindia Belanda memberlakukan kebijakan politik pintu terbuka dengan memperbolehkan pengusaha dan modal dari berbagai bangsa masuk ke Hindia Belanda. ${ }^{23}$ Pemberlakukan kebijakan ini menandai dimulainya era liberal dan ekonomi kapitalistik di Hindia Belanda. Di mana perusahaan yang ada ditandai dengan sifatnya yang padat modal, penggunaan areal pertanahan yang luas, penggunaan tenaga kerja upahan, struktur dan organisasi kerja yang rapi dan lain sebagainya. ${ }^{24}$

Sebelum tahun 1800, bentuk kerja di perkebunan dilakukan untuk konsumsi sendiri (tidak untuk mendapatkan upah) atau sebab-sebab lain. Dalam bentuk kerja tidak berupah ini, jenis kerja berkebun waktu itu muncul di dalam masyarakat dalam bentuk kerja wajib untuk kalangan elite setempat, kerja karena terlibat utang yang harus dilunasi dengan bekerja mengabdi pada si pemberi utang, dan dalam bentuk perbudakan. ${ }^{25}$ Setelah dibukanya praktik ekonomi liberal di Hindia Belanda, terjadi perubahan signifikan dalam tata kelola perkebunan, terutama sekali sejak berlakunya Undang-Undang Agraria 1870, maka perusahaan swasta

\footnotetext{
${ }^{23}$ D. H. Burger dan Parajudi Atmosudirdjo,. Sedjarah Ekonomis Sosiologis Indonesia Jilid 1, (Jakarta: Pradnjaparamita, 1962), hlm. 209.

${ }^{24}$ Sartono Kartodirdjo dan Djoko Suryo, Sejarah Perkebunan di Indonesia : Kajian SosialEkonomi, (Yogyakarta: Aditya Media, 1991), hlm. 4.

${ }^{25}$ Suri Suroto, "Gerakan Buruh dan Permasalahannya, dalam Prisma, No. 11, Tahun 1984.
} 
telah diberikan wewenang penuh untuk mengontrol dan memonopoli sistem ekonominya sendiri dengan sedikit sekali kontrol dari pemerintah. ${ }^{26}$

Kapitalisasi dan penggunaan uang masuk ke Indonesia ketika pada abad ke19 Raffles mulai memasyarakatkan penggunaan uang sebagai imbalan pekerjaan di kalangan masyarakat Jawa. Hal ini dikarenakan pada masa sebelumnya peredaran uang sangat terbatas, yakni pada kalangan penguasa dan pedagang saja. ${ }^{27}$

Kapitalisme juga mengubah wajah pola penguasaan ekonomi oleh bangsa Barat atas wilayah Nusantara yang amat kaya. Mereka tidak lagi membeli barangbarang mentah untuk ekspor dari pedagang-pedagang Nusantara untuk dijual di pasaran Eropa. Namun mereka lah yang langsung mengadakan penanaman bahanbahan ekspor itu dengan cara menguasai tanah yang sebelumnya dikuasai penduduk pribumi untuk dijual tanpa harus melalui perantara pedagang lokal.

Hal demikian juga terjadi di Sumatera Timur, para pengusaha asing berlomba-lomba untuk membuka lahan perkebunan tembakau langsung ketimbang membeli dari pedagang lokal. Hal ini tentu saja terkait dengan keinginan mereka untuk mendapatkan keuntungan yang sebesar-besarnya. Upaya Nienhuys tersebut lah yang menjadi pembuka jalan para pengusaha Barat untuk datang dan menanamkan modalnya di Sumatera Timur.

Pada masa-masa awal, yakni pada Maret 1864 perkebunan Nienhuys menghasilkan tembakau sebanyak 50 pak. Hasil panen tersebut kemudian dikirim ke Rotterdam di Belanda, untuk dijual dan diuji kualitasnya. Ternyata daun tembakau tersebut sangat baik dan berkualitas tinggi untuk pembungkus cerutu. Di sana harga tembakau Nienhuys terjual seharga 48 sen gulden per $1 / 2$ kilogram. Setahun kemudian, pada tahun 1865 produksi tembakau yang dihasilkan oleh perkebunan milik Nienhuys meningkat menjadi 149 pak. Produksi ini juga dikirim

\footnotetext{
${ }^{26}$ Sartono Kartodirdjo dan Djoko Suryo, Op.Cit, hlm. 80.

${ }^{27}$ D. H. Burger dan Parajudi Atmosudirdjo,. Sedjarah Ekonomis Sosiologis Indonesia Jilid 1, (Jakarta: Pradnjaparamita, 1962), hlm. 152.
} 
ke Rotterdam. Untuk pengiriman kedua kali ini harga tembakau tersebut meningkat menjadi 149 sen gulden per $1 / 2$ kilogram. $^{28}$

Peluang dari penanaman tembakau yang menguntungkan kini telah terbukti. Tembakau-tembakau berkualitas dari Deli mulai menarik perhatian berbagai kalangan. Salah satunya adalah NHM (Nederlandsche Handelmaatschappij), sebuah perusahaan perdagangan milik Belanda, yang tertarik untuk menanamkan modalnya di usaha perkebunan milik Nienhuys. NHM bersedia memberikan sejumlah uang sebagai investasi kepada Nienhuys dengan imbalan 50\% sahamnya kan dimiliki oleh NHM. Dari modal yang diberikan itu Nienhuys bersama-sama dengan G.C. Clemen dan P.W. Janssen mendirikan sebuah perusahaan dengan nama Deli Maatschappij.

Deli Maatschappij mulai mengembangkan usahanya dengan modal awal sebesar $f$ 300.000. Dengan tanah seluas 7000 ha pada awal pendiriannya, dapat dihasilkan 2868 bal tembakau, sedangkan setahun setelahnya hanya menghasilkan 1381 bal tembakau. Kemudian dari hasil panen tahun 1870, Deli Maatschappij telah dapat membayar bunga saham dari keuntungannya, dan empat tahun kemudian, pada 1874 bunganya telah meningkat menjadi 80\%. Untuk lebih jelasnya mengenai perkembangan saham dan modal Deli Maatschappij dapat dilihat dalam tabel berikut:

Tabel Perkembangan Saham dan Modal Deli Maatschappij 1870-1891

\begin{tabular}{|c|c|c|c|c|}
\hline $\begin{array}{c}\text { Hasil } \\
\text { Panen }\end{array}$ & $\begin{array}{c}\text { Jumlah } \\
\text { Perkebunan }\end{array}$ & $\begin{array}{c}\text { Bunga saham di } \\
\text { atas saham } f\end{array}$ & $\begin{array}{c}\text { Modal } \\
\text { Perusahaan }\end{array}$ & $\begin{array}{c}\text { Jumlah bunga } \\
\text { saham }\end{array}$ \\
\hline
\end{tabular}

\footnotetext{
${ }^{28}$ Sjafri Sairi, "Kebijaksanaan Perburuhan di Perkebunan Sumatera Timur Pada Masa Kolonial”,
} Jurnal Antropologi Indonesia, No. 52, Tahun 1997, hlm. 55. 


\begin{tabular}{|c|c|c|c|c|}
\hline Tahun & & 1000 & & \\
\hline 1870 & 1 & $f 320$ & $f 300.000$ & $f 60.000$ \\
\hline 1871 & 1 & $f 330$ & $f 315.000$ & $\begin{array}{ll}f & 103.000\end{array}$ \\
\hline 1872 & 3 & $f 600$ & $f 351.000$ & $f 210.000$ \\
\hline 1873 & 5 & $f 700$ & $f 500.000$ & $f 350.000$ \\
\hline 1874 & 7 & $f 800$ & $f 500.000$ & $f 400.000$ \\
\hline 1875 & 7 & $f 910$ & $f 500.000$ & $f 455.000$ \\
\hline 1876 & 8 & $f 1130$ & $f 500.000$ & $f 565.000$ \\
\hline 1877 & 9 & $f 225$ & $f 800.000$ & $f 180.000$ \\
\hline 1878 & 10 & $f 379$ & $f 2.000 .000$ & $f 758.000$ \\
\hline 1879 & 11 & $f 332$ & $f 2.000 .000$ & $f 664.000$ \\
\hline 1880 & 11 & $f 373$ & $f 2.000 .000$ & $f 746.000$ \\
\hline 1881 & 11 & $f 650$ & $f 2.000 .000$ & $f 1.300 .000$ \\
\hline 1882 & 10 & $f 1010$ & $f 2.000 .000$ & $f 2.020 .000$ \\
\hline 1883 & 11 & $f 777$ & $f 2.000 .000$ & $f 1.554 .000$ \\
\hline 1884 & 12 & $f 1075$ & $f 2.000 .000$ & $f 2.150 .000$ \\
\hline 1885 & 12 & $f 1085$ & $f 2.000 .000$ & $f 2.170 .000$ \\
\hline 1886 & 12 & $f 1098$ & $f 2.000 .000$ & $f 2.196 .000$ \\
\hline 1887 & 12 & $f 425$ & $f 2.000 .000$ & $f 904.000$ \\
\hline
\end{tabular}




\begin{tabular}{|l|l|l|l|l|}
\hline 1888 & 15 & $f 352$ & $f 4.000 .000$ & $f 1.408 .000$ \\
\hline 1889 & 16 & $f 793$ & $f 3.172 .000$ & $f 3.172 .000$ \\
\hline 1890 & 21 & - & $f 4.000 .000$ & $f-359.000$ \\
\hline 1891 & 21 & $f 228$ & $f 4.000 .000$ & $f-1.152 .000$ \\
\hline
\end{tabular}

Sumber: Deli Maatschappij, Gedenkschrift Bij Gelegenheid van het Vijftigjarig Bestaan, (Amsterdam: 1919), hlm. 73

Tahun ke tahun usaha Deli Maatschappij terus maju, sehingga pada 1873 modalnya sudah berkembang menjadi $f 500.000$ dan tahun 1876 modalnya sudah mencapai $f$ 800.000. Usaha ini terus berkembang, sehingga pada 1907 modal usaha mereka sudah mencapai $f 9.000 .000$ dengan luas konsesi tanah perkebunan sekitar 120.000 hektar yang terdiri dari 21 perkebunan dengan masing-masing memiliki administrator dan dibantu oleh 4 sampai 6 orang asisten setiap perkebunan. ${ }^{29}$

Perkembangan Deli Maatschappij berjalan sesuai dengan rencana-rencana yang dibuat Nienhuys. Perusahaan ini selain memusatkan kegiatannya pada produksi tembakau, namun juga meneruskan perhatiannya pada pala dan kelapa. Tembakau yang dihasilkan oleh Deli Maatschappij sangat masyhur di pasaran Eropa. Tembakau dengan kualitas yang sangat baik itu digunakan sebagai pembungkus cerutu. Rasa yang dihasilkan sangat digemari para penikmat cerutu di Eropa dan wilayah lainnya. Deli Maatschappij merupakan perusahaan perkebunan tembakau pertama di Sumatera Timur, dan dengan cepat menjadi perusahaan

\footnotetext{
${ }^{29}$ J. Paulus, Op.Cit., hlm. 580.
} 
terbesar dan paling penting di wilayah ini. Mereka juga memiliki pengaruh yang luar biasa dalam perkembangan ekonomi di Sumatera Timur. ${ }^{30}$

Ekspor Kesultanan Deli, 1863-1867

\begin{tabular}{|l|l|l|l|l|l|}
\hline Komoditi (dalam pikul) & $\mathbf{1 8 6 3}$ & $\mathbf{1 8 6 4}$ & $\mathbf{1 8 6 5}$ & $\mathbf{1 8 6 6}$ & $\mathbf{1 8 6 7}$ \\
\hline Lada Hitam & 17.600 & 38.860 & 19.200 & 5000 & 3400 \\
\hline Tembakau & 373 & 507 & 801 & 1200 & 1300 \\
\hline Pala & 620 & 9100 & 4260 & 3855 & 9980 \\
\hline Buah Pinang & - & - & 120 & 400 & 345 \\
\hline
\end{tabular}

Sumber: Karl J. Pelzer, Toean Keboen dan Petani: Politik Kolonial dan Perjuangan Agraria. Jakarta: Penerbit Sinar Harapan, 1985.

Melihat keuntungan dari hasil usaha yang diperoleh Nienhuys cukup menggiurkan, banyak pengusaha-pengusaha perkebunan lainnya tertarik untuk mengadu peruntungan di Sumatera Timur. Keberhasilannya dalam menghasilkan tembakau Deli dengan kualitas terbaik yang sangat laku dengan harga tinggi di pasar Eropa dan Amerika kala itu dengan cepat menarik perhatian pengusahapengusaha besar di negeri Belanda untuk menanam modal mereka pada perkebunan-perkebunan tembakau di Deli. Dalam waktu singkat, para pengusahapengusaha Belanda berlomba-lomba untuk mendirikan perkebunan-perkebunan tembakau yang besar di Deli. ${ }^{31}$

${ }^{30}$ Karl J. Pelzer, Op.Cit., hlm. 58. Lihat juga Thee Kian Wie, Op.Cit., hlm. 6.
${ }^{31}$ Daliman, Op.Cit., hlm. 51. 
Mereka meniru apa yang dilakukan oleh Nienhuys untuk mendapatkan keuntungan yang besar dalam budidaya tembakau. Tidak lama berselang, datang investor-investor asing untuk menanamkan modalnya di Sumatera Timur untuk menanam investasi dan mendirikan perusahaan perkebunan tembakau seperti yang dilakukan pengusaha-pengusaha asal Inggris, Belgia, Prancis, dan Jerman.

Keberhasilan dalam menarik modal asing untuk menanamkan modal untuk pengembangan perkebunan tembakau di Sumatera Timur sejak mulai dasawarsa keenam abad ke-19 tersebut, tidak hanya dilatarbelakangi oleh jaminan keuntungan yang besar dari harga jual tembakau Deli di pasar dunia, namun juga akibat kemudahan yang diberikan oleh para sultan kepada para pemodal asing untuk memperoleh hak konsesi tanah di Sumatera Timur. Untuk mendapatkan kepemilikan tanah mereka kemudian meminta izin konsesi dari Sultan Deli, Sultan Serdang dan Sultan Langkat. Pengusaha-penguasaha asing diberikan konsesi tanah yang mudah dan murah oleh Sultan, bahkan Sultan tanpa kemauan rakyat telah mengkonsesikan tanah rakyat. ${ }^{32}$

Masuknya investor-investor asing dalam menanamkan modalnya di daerah ini menjadikan perkebunan sebagai tulang punggung perekonomian Sumatera Timur. Banyaknya investor yang menanamkan modalnya membuat terjadinya ekspansi wilayah perkebunan di Sumatera Timur. Dua tahun setelah panen tembakau pertama, dua orang Swiss dan satu Jerman datang ke Deli untuk menanamkan modal dalam industri tembakau. Lalu pada 1872 tiba 75 orang, kemudian pada 1884 melonjak menjadi 688 orang pengusaha.

Ekspansi wilayah perkebunan juga mengakibatkan adanya penambahan jumlah perusahaan-perusahaan perkebunan milik asing selain Belanda. Tidak hanya di Labuhan, ekspansi perkebunan baru juga dibuka di daerah Martubung,

${ }^{32}$ Kemala Chandrakirana. "Geertz dan Masalah Kesukuan.” Prisma, No. 2, Jakarta: LP3ES, 1989, hlm. 9 . 
Sunggal (1869), Sungai Beras dan Klumpang (1875), sehingga pada tahun 1873 jumlah perusahaan perkebunan di Sumatera Timur mencapai 13 perkebunan. Setahun berikutnya menjadi 22 perusahaan. Hingga pada 1876 jumlahnya membengkak menjadi $40 .^{33}$

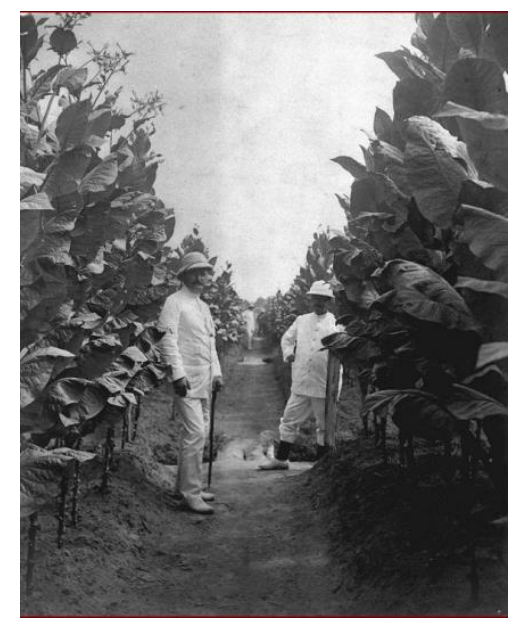

\section{Gambar 4: Pengawas perkebunan Deli Maatschappij sedang mengunjungi kebun tembakau di Deli (Sumber: Tropen Museum)}

Selain Deli Maatschappij, terdapat pula perusahaan-perusahaan perkebunan tembakau lain yang dimiliki oleh para pengusaha yang berasal dari Eropa. Perusahaan-perusahaan ini juga memainkan peranan yang besar dalam mempopulerkan tembakau Deli ke pasaran Eropa. Mereka di antaranya adalah Senembah Maatschappij, de Deli-Batavia Maatschappij, de Amsterdam-Deli Maatschappij, de Tabak Maatschappij Arendsburg, dan the United Langkat Plantations Company. ${ }^{34}$ Perusahaan-perusahaan perkebunan ini selain dimiliki oleh pengusaha Belanda, juga terdapat pengusaha Eropa lainnya termasuk juga yang berasal dari Amerika Serikat. Pada tahun-tahun berikutnya, perusahaan-perusahaan

\footnotetext{
${ }^{33}$ Karl J. Pelzer, Op.Cit., hlm. 65-89.

${ }^{34}$ Thee Kian Wie, Op.Cit., hlm. 7.
} 
perkebunan asing bertambah secara signifikan. Penambahan perusahaan perkebunan asing di Sumatera Timur dapat dilihat dalam tabel berikut:

\section{Perkembangan Barang Modal dalam Industri Perkebunan di Sumatera Timur dalam $f$ 1.000.000}

\begin{tabular}{|l|l|l|l|l|l|}
\hline Tahun & Belanda & Inggris & Amerika & Lain-lain & Jumlah \\
\hline 1913 & 110 & 57 & 17 & 23 & 206 \\
\hline 1924 & 242 & 80 & 75 & 74 & 423 \\
\hline 1929 & 361 & 125 & 53 & 104 & 642 \\
\hline
\end{tabular}

Sumber: Pieter Cruetzberg dan J.T.M. van Laanen (eds), Sejarah Statistik Ekonomi Indonesia, (Jakarta: Yayasan Obor Indonesia, 1987), hlm. 258.

Pada periode awal abad ke-20 kondisi perekonomian di Sumatera Timur berkembang pesat akibat dari keuntungan yang amat besar dari sektor perkebunan. Dari data tabel di atas, pada periode ini, perusahaan-perusahaan asing meningkat, terutama sekali pada akhir dekade 1920 yang berjumlah 642 perusahaan. Perusahaan perkebunan ini didominasi oleh tiga negara utama penanam modal di Deli, yakni Belanda, Inggris, dan Amerika Serikat. Sementara dari negara lain, dimasukkan ke dalam kolom lain-lain karena jumlahnya yang tidak besar. Perusahaan-perusahaan perkebunan itu paling banyak berasal dari Belanda, yaitu sebesar 713 perusahaan selama periode 1913-1929. Untuk perusahaan dari Inggris total terdapat 262 perusahaan, dan Amerika Serikat sebanyak 201 perusahaan.

\section{Angka-angka ekspor perkebunan di Hindia Belanda awal abad ke-20}




\begin{tabular}{|l|l|l|l|}
\hline Jenis & $\mathbf{1 9 0 0}$ & $\mathbf{1 9 0 5}$ & $\mathbf{1 9 1 3}$ \\
\hline Gula & $f 73.700 .000$ & $f 84.000 .000$ & $f 213.200 .000$ \\
\hline Karet & $f 16.000 .000$ & $f 14.600 .000$ & $f 60.600 .000$ \\
\hline Minyak & $f 4.600 .000$ & $f 21.400 .000$ & $f 108.500 .000$ \\
\hline Tembakau & $f 32.100 .000$ & $f 38.500 .000$ & $f 92.100 .000$ \\
\hline Kopra & $f 10.300 .000$ & $f 30.400 .000$ & $f 55.100 .000$ \\
\hline Teh & $f 4.200 .000$ & $f 7.100 .000$ & $f 21.500 .000$ \\
\hline $\begin{array}{l}\text { Timah dan biji } \\
\text { timah }\end{array}$ & $f 8.200 .000$ & $f 5.300 .000$ & $f 6.000 .000$ \\
\hline Kopi & $f 24.700 .000$ & $f 18.900 .000$ & $f 20.400 .000$ \\
\hline Lain-lain & $f 46.200 .000$ & $f 71.800 .000$ & $f 36.600 .000$ \\
\hline Jumlah & $f 230.000 .000$ & $f 292.000 .000$ & $f 614.000 .000$ \\
\hline
\end{tabular}

Sumber Noek Hartono, 1976, Bank Indonesia: Sejarah Lahir dan Pertumbuhannya. Bank Indonesia: naskah tidak diterbitkan.

Perkebunan kemudian dijadikan sebagai Cultuursgebied ter Oostkust van Sumatra yang akhirnya memunculkan animo yang besar dalam pengembangan perkebunan tembakau. Dari Deli, Langkat, dan Serdang yang menjadi kawasan inti, perkebunan juga diperluas ke kawasan Simalungun dan Asahan. Sumatera Timur mengalami suatu perkembangan yang sangat pesat dan memiliki keistimewaan dalam sejarah kolonial mana pun juga saat itu. Lebih kurang 25 tahun, setelah Nienhuys untuk pertama kali membuka perkebunan tembakau di Deli, topografi Sumatera Timur berubah sama sekali dari hutan belantara akhirnya menjelma 
menjadi dipenuhi oleh hamparan perkebunan tembakau besar yang menyusuri seluruh kawasan pantai Sumatera Timur sepanjang 200 km. ${ }^{35}$

\section{E. Dampak Pembukaan Perkebunan Tembakau di Sumatera Timur}

Pembukaan perkebunan di Sumatera Timur membawa perubahan drastis terhadap masyarakat Sumatera Timur, khususnya kaum aristokrat Melayu. Ekonomi kolonial Belanda dengan sistem ekonomi perkebunannya telah mendatangkan kesejahteraan hampir semua raja-raja di kawasan ini. Sultan Deli, Sultan Langkat, Sultan Serdang, dan Sultan Asahan adalah raja-raja yang paling banyak mendapat keuntungan dari pembukaan perkebunan di wilayah tersebut. Keuntungan tersebut semakin besar terutama karena adanya kebijakan Pemerintah kolonial yang masih memperbolehkan raja-raja tersebut menjalankan kekuasaan hukum adat mereka, antara lain yang terpenting adalah tanah. Imbalan honorarium dari perusahaan perkebunan terus-menerus mengalir ke kantong pribadi para sultan dan datuk yang berkuasa di Sumatera Timur. Pada tahun 1915, 39,2 persen penghasilan pajak di Deli, dari 37,9 \% di Langkat, dan 51,9 \% di Serdang masuk ke kantong pribadi sultan dan datuk-datuknya. Keuntungan dari pajak itu masih ditambah lagi dengan gaji resmi dari pemerintah kolonial dan honorarium dari perusahaan-perusahaan perkebunan. ${ }^{36}$ Sementara itu di Simalungun dan Tanah Karo, raja-rajanya yang diikat dengan Korte Verklaring, masing-masing memperoleh 16,1\% dan 10,9\%.

Sultan Machmoed dari Kerajaan Langkat adalah yang paling kaya di antara mereka. Dengan hasil honorarium dari perusahaan minyak di Pangkalan Brandan, pendapatannya pada tahun 1931 mencapai $f$ 184.568. Sultan Amaloedin dari Deli mendapat $f$ 472.094 dan Sultan Soelaiman dari Serdang memeroleh $f$ 103.346.

\footnotetext{
${ }^{35}$ Ann Laura Stoler, Op.Cit., hlm 29-30. Lihat pula R.Z. Leirissa, Op.Cit., hlm. 32.

${ }^{36}$ Anthony Reid, Perjuangan Rakyat: Revolusi dan Hancurnya Kerajaan di Sumatera Utara, (Jakarta: Sinar Harapan. 1987), hlm. 89
} 
Raja-raja Simalungun, meskipun tidak sehebat Sultan-sultan Melayu juga menerima keuntungan yang besar dari perkebunan itu. Di samping gaji mereka sebanyak $f 6.720$ setahun, dua rajanya yang terkaya menerima uang jalan sebesar $f$ 1800 setahun dan menerima upeti dari rakyatnya. Para Sibayak di Tanah Karo mendapat gaji rata-rata $f 2.400$ setahun, jauh lebih sedikit dan gaji Sultan-sultan Melayu. Perinciannya adalah sebesar $f 3.960$ setahun untuk Sibayak Lingga dan $f$ 1.200 setahun untuk Sibayak Kutabuluh. ${ }^{37}$

Peningkatan kesejahteraan yang luar biasa ini berdampak pada perubahan gaya hidup sebagian sultan dan bangsawan Sumatera Timur, khususnya Melayu. Sebelum kedatangan Belanda dan dibukanya perkebunan-perkebunan di Sumatera Timur, kaum bangsawan Melayu termasuk sultan-sultannya berada dalam keadaan yang melarat. Pasca kemunculan sistem ekonomi perkebunan, mereka mengalami peningkatan ekonomi yang signifikan. Para sultan tersebut mampu membangun istana yang megah, membeli mobil mewah, bahkan pesiar ke Eropa. Gaya hidup mewah ini sudah mewarnai kehidupan mereka sehari-hari. Sultan-sultan Melayu kerap kali mengadakan pesta-pesta untuk menyambut tamu-tamu penting, terutama dari kalangan orang-orang Eropa dan bangsawan. Untuk menunjukkan kebesaran dinastinya, mereka membentuk pasukan yang terdiri dari para keluarga bangsawan. ${ }^{38}$

Peningkatan ekonomi di Sumatera Timur tidak selalu berdampak positif. Terdapat pula efek negatif dari hal tersebut, yakni terjadinya jurang pemisah yang lebar antara kaum elite Eropa beserta bangsawan kerajaan dengan orang-orang Cina, Jawa, India, Banjar, Sunda, Mandailing, Bawean, Batak, Gayo, Alas, dan sebagainya yang sebagian besar menjadi buruh di perkebunan-perkebunan Sumatera Timur. Susunan golongan di Sumatera Timur pada zaman kolonial

${ }^{37}$ Suprayitno.2001. Mencoba (Lagi) Menjadi Indonesia. Yogyakarta: Yayasan untuk Indonesia. Hal. $22-23$

${ }^{38}$ Ibid. 
Belanda benar-benar kompleks dan bervariasi antara satu daerah dengan daerah lainnya. Lengenberg menggambarkan sebagai berikut:

Pada lapisan atas terdapat kaum elite penguasa kolonial yang terdiri dari beberapa lapisan. Pertama, orang-orang Eropa, yaitu pejabat-pejabat kolonial, administrator perkebunan, dan para pengusaha.Kedua, keluarga enam kesultanan Melayu, Langkat, Deli, Serdang dan Asahan, Kota Pinang, dan Siak. Ketiga adalah para raja Karo dan Simalungun, kaum intelektual Indonesia berpendidikan barat (dokter, pengacara, pejabat, sipil kolonial senior), dan para pedagang kaya, Cina, India, dan pribumi. ${ }^{39}$

Di balik gemerlap dan kemewahan para elite di Sumatera Timur, kepentingan dan kesejahteraan hidup penduduk yang ada di daerah tersebut terabaikan. Sehingga, semakin lama usaha perkebunan itu dipandang oleh penduduk tidak lebih dari lambang penindasan dan kesewenang-wenangan, karena hak-hak istimewa golongan elite sangat diutamakan di satu sisi, sementara di sisi lain hak dan nasib golongan kecil sangat diabaikan. ${ }^{40}$

Sementara itu, Perkembangan perusahaan perkebunan telah menciptakan perubahan besar dalam aspek kependudukan dan perkotaan di Sumatera Timur. Salah satunya adalah perubahan komposisi demografi. Pada pertengahan abad ke19, jumlah penduduk Sumatera Timur diperkirakan berjumlah 150.000 jiwa. Dalam tempo 80 tahun terjadi peningkatan beberapa kali lipat yakni menjadi 1.693.200 jiwa. Penyebab hal tersebut adalah kedatangan kuli-kuli dari Jawa dan Cina dalam jumlah besar ke perkebunan-perkebunan di Sumatera Timur dan adanya migrasi

\footnotetext{
${ }^{39}$ Michael van Langenberg, "East Sumatra: Accomodating an Indonesian Nation Within a Sumatran Residency", dalam Audrey Kahin, Regional Dinamics of Indonesian Revolution: Unity from Diversity, (Hawaii: University of Hawaii, 1985), hlm. 155

${ }^{40}$ Andi Suwirta, "Buruh Perkebunan di Sumatera Timur: Sebuah Tinjauan Sejarah", dalam Historia Jurnal Pendidikan Sejarah, No. 5, Vol. III, Juni 2002, hlm. 23.
} 
orang-orang dari Tapanuli, Aceh, dan Sumatera Barat. Hal ini menyebabkan komposisi demografi di Sumatera Timur tidak lagi didominasi oleh orang-orang Melayu Sumatera Timur, melainkan didominasi oleh para pendatang. Dalam tahun 1929 diperkirakan terdapat 301.936 orang kuli yang bekerja di perkebunan. Jumlah ini terdiri dari 275.233 kuli dari Jawa dan 26.703 kuli asal Cina. Penduduk dari keseluruhan penduduk Sumatera Timur. Dengan demikian, jumlah penduduk Sumatera Timur lebih dari separuhnya adalah para penduduk pendatang yang bukan berasal dari Sumatera. Untuk melihat perkembangan komposisi demografi penduduk di Sumatera Timur dapat dilihat dalam tabel berikut:

Tabel Komposisi Penduduk Sumatera Timur Periode 1850-1915

\begin{tabular}{|l|l|l|l|l|l|}
\hline Tahun & Eropa & \multicolumn{1}{|c|}{ Cina } & $\begin{array}{c}\text { Timur } \\
\text { Asing }\end{array}$ & Pribumi & Jumlah \\
\hline 1880 & 552 & 25.700 & 2.533 & 90.000 & 118.705 \\
\hline 1900 & 2.097 & 103.768 & 9.028 & 306.035 & 420.928 \\
\hline 1905 & 2.667 & 99.236 & 15.573 & 450.941 & 568.417 \\
\hline 1915 & 5.200 & 132.000 & 14.320 & 681.800 & 833.320 \\
\hline
\end{tabular}

Sumber: Mededeeling van het Oostkust van Sumatra Instituut, No. 26, hlm. 35.

Komposisi demografi di Sumatera Timur dalam tabel tersebut memperlihatkan adanya peningkatan signifikan dari penduduk pribumi. Penduduk pribumi ini diisi sebagian besar oleh para buruh perkebunan dan para pendatang yang secara sengaja datang ke Sumatera Timur untuk mengadu nasib mereka demi mendapatkan kehidupan yang lebih baik. Secara teori, para pengusaha perkebunan atas permintaan yang bersangkutan, wajib memulangkan para buruh ke tempattempat asal mereka masing-masing pada akhir kontrak. Namun, ternyata setelah puluhan tahun bermukim di wilayah perkebunan, banyak dari para buruh tersebut - 
Cina dan Jawa - yang lebih memilih untuk menetap setelah kontrak mereka habis. Mereka bermukim baik di kampung-kampung maupun di kota-kota yang sedang berkembang. Hanya bekas butuh yang bermukim di tengah-tengah penduduk asli berada di bawah yurisdiksi penguasa-penguasa Sumatera Timur. Membanjirnya para bekas buruh memasuki kampung-kampung menciptakan kepadatan yang luar biasa di wilayah-wilayah sekitar perkebunan. Dalam waktu singkat, secara jumlah penduduk asli dilampaui oleh buruh Cina dan Jawa.

Selain demografi, dampak lain dari perkembangan ekonomi akibat usaha perkebunan di Sumatera Timur adalah muncul dan berkembangnya kota-kota baru di wilayah sekitar perkebunan. Salah satunya Pematang Siantar, yang menjadi sebuah pusat administrasi dan ekonomi yang penting dan sekaligus menjadi jalur silang yang menghubungkan wilayah Tapanuli, Karo, Simalungun, dan dataran rendah Sumatera Timur.

Kota lain yang muncul akibat pembukaan perkebunan adalah kota Medan Putri, yang kemudian sekarang dikenal dengan Medan. Medan sebagai pusat administrasi pemerintahan dan ekonomi perkebunan telah berkembang dengan cepat. Perkembangan Medan menjadi pusat perdagangan telah mendorongnya menjadi pusat pemerintahan. Geliat ekonomi perkebunan juga memengaruhi para pejabat Belanda di Sumatera Timur untuk mengubah lokasi pusat pemerintahan di Sumatera Timur. Bermula ketika tahun 1879, Ibukota Asisten Residen Deli dipindahkan dari Labuhan ke Medan. Lalu pada perkembangannya, pada 1 Maret 1887, Medan juga menjadi pusat administrasi Keresidenan Sumatera Timur yang sebelumnya berada di Bengkalis. Tidak ketinggalan pula para elite pribumi yang turut memindahkan pusat kekuasaannya ke Medan. Istana Kesultanan Deli yang semula berada di Kampung Bahari (Labuhan) juga pindah dengan selesainya 
pembangunan Istana Maimun pada tanggal 18 Mei 1891, dan dengan demikian Ibukota Kesultanan Deli telah resmi pindah ke Medan. ${ }^{41}$

Oleh sebab kemakmuran dan banyaknya investasi modal asing itu tertanam dalam bidang perkebunan, maka pada 1915, status Keresidenan Sumatera Timur sudah ditingkatkan menjadi Gouvernement yang dipimpin seorang Gubernur di Medan. ${ }^{42}$ Hingga kemudian pada 1918, Kota Medan resmi menjadi Gemeente (Kota Praja) dengan Walikota Baron Daniel Mac Kay. Berdasarkan "Acte van Schenking" (Akte Hibah) Nomor 97 Notaris J.M. de-Hondt Junior. Pada tanggal 30 Nopember 1918, Sultan Deli menyerahkan tanah kota Medan kepada Gemeente Medan, sehingga Medan secara resmi menjadi wilayah di bawah kekuasaan langsung Hindia Belanda, tidak lagi di bawah Kesultanan Deli. Pada masa awal Kotapraja ini, Medan masih terdiri dari 4 kampung, yaitu Kampung Kesawan, Kampung Sungai Rengas, Kampung Petisah Hulu dan Kampung Petisah Hilir. ${ }^{43}$

Perkembangan ekonomi dan kemunculan kota-kota baru telah melahirkan suatu budaya baru yang terlepas dari lingkungan budaya asalnya dan wewenang Kerajaan Melayu. Mereka adalah rakyat gubernemen, bukan rakyat kerajaan. Di Medan muncul suatu kesadaran baru, yakni kesadaran akan identitas ke-Indonesiaan lewat perkembangan pesat penggunaan bahasa Indonesia sebagai bahasa yang dipakai media penerbitan seperti Pewarta Deli, Sinar Deli, Pelita Andalas, dan media lainnya yang digagas oleh golongan Bumiputera. Identitas ini semakin menguat ketika Sumpah Pemuda tahun 1928 mengukuhkan Bahasa Indonesia sebagai Bahasa persatuan. Pengakuan ini penting artinya dalam menumbuhkan budaya baru yang bersifat nasional di kota-kota besar di Indonesia, khususnya di Medan.

${ }^{41}$ Tengku Luckman Sinar Basarshah, Bangun dan Runtuhnya Kerajaan Melayu di Sumatera Timur, (Medan: Yayasan Kesultanan Serdang, 2006), hlm. XIII

${ }^{42}$ Ibid.

${ }^{43}$ L. J. Winckel, et. al, Gemeente Medan 1909-1934, (Medan: Tanpa Penerbit, 1934), hlm. 15. 


\section{F. Penutup}

Pada paruh kedua abad ke-19, Sumatera Timur merupakan wilayah yang penting dalam perkembangan perekonomian Hindia Belanda di pulau Sumatera. Dalam waktu kurang dari satu abad Sumatera Timur yang sebelumnya hutan belantara telah menjelma menjadi wilayah menjadi wilayah perkebunan yang makmur. Dalam perkembangan ekonomi perkebunan, Sumatera Timur mengalami eksploitasi secara besar-besaran. Eksploitasi tersebut diantaranya adalah pembukaan lahan-lahan hutan, penanaman tanaman komoditas, mengalirnya investasi swasta dalam jumlah besar, serta masuknya tenaga kerja dari luar wilayah ini semakin mendukung eksploitasi terhadap wilayah ini sehingga mengalami perkembangan yang sangat pesat.

Keberhasilan budidaya perkebunan tembakau telah menarik para investor asing untuk menanamkan modalnya dengan membuka perusahaan-perusahaan perkebunan di Sumatera Timur. Kualitas tembakau yang amat baik membuat para investor tersebut tidak ragu untuk mengalirkan dana mereka ke wilayah ini. Hal ini menyebabkan arus investasi di bidang perkebunan mengalir dengan sangat deras ke wilayah perkebunan. Dari situ mulailah era kapitalisasi ekonomi di Sumatera Timur dengan banyaknya perusahaan-perusahaan perkebunan asing.

Kapitalisasi ekonomi perkebunan di Sumatera Timur membawa beberapa dampak yang signifikan bagi perkembangan ekonomi di Sumatera Utara. Di antaranya adalah: Pertama, ekonomi perkebunan membawa perubahan gaya hidup di kalangan sultan dan bangsawan Melayu di Sumatera Timur. Kekayaan ini mereka dapatkan dari hasil konsesi lahan perkebunan yang disewakan kepada para pengusaha asing. Kedua, terjadinya jurang sosial akibat dari perkembangan ekonomi yang terjadi. Di satu sisi kalangan elite mengalami peningkatan kekayaan 
yang masif, sementara kalangan rakyat kecil yang didominasi oleh buruh perkebunan tidak mengalami peningkatan kekayaan yang berarti. Ketiga, perkembangan perkebunan di Sumatera Timur membuat perubahan komposisi demografi di wilayah tersebut. Setelah munculnya perkebunan-perkebunan, penduduk di Sumatera Timur tidak lagi didominasi oleh penduduk Melayu lokal, melainkan didominasi oleh para pendatang yang sebagian besar adalah para buruh perkebunan. Keempat, perkembangan ekonomi di Sumatera Timur memunculkan kota-kota baru yang menjadi pusat kegiatan ekonomi di wilayah itu. Medan merupakan contoh paling nyata dari kemunculan kota-kota akibat perkebunan. Sebagai penutup, pada akhirnya kehadiran bangsa Belanda sebagai yang kemudian diikuti oleh pihak pengusaha swasta dari daratan Eropa dan Amerika yang mengembangkan usaha perkebunan, pertambangan, dan industri lainnya hingga dekade 1940-an di Sumatera Timur sama sekali tidak berdampak positif terhadap kesejahteraan bagi masyarakat pribumi kebanyakan. Kuasa ekonomi yang mereka miliki hanya bertujuan untuk menciptakan aktivitas ekonomi yang semata-mata hanya untuk memperkaya diri sendiri. 


\section{DAFTAR PUSTAKA}

Anderson, John. 1971. Mission to the East Coast of Sumatra in 1823, Oxford in Asia Historical Reprints. Kuala Lumpur: Oxford University Press.

Basarshah, Tengku Luckman Sinar. 2005. Bangun dan Runtuhnya Kerajaan Melayu di Sumatera Timur. Medan: Yayasan Kesultanan Serdang.

Breman, Jan. 1997. Menjinakkan Sang Kuli: Politik Kolonial, Tuan Kebun, dan Kuli di Sumatera Timur Pada Awal Abad ke-20. Jakarta: Pustaka Utama Grafiti.

Burger, D. H. dan Parajudi Atmosudirdjo. 1962. Sedjarah Ekonomis Sosiologis Indonesia Jilid 1. Jakarta: Pradnjaparamita.

Chandrakirana, Kemala. 1989. "Geertz dan Masalah Kesukuan.” Prisma, No. 2, Jakarta: LP3ES, 1989, hlm. 9.

Cruetzberg, Pieter dan J.T.M. van Laanen (eds). 1987. Sejarah Statistik Ekonomi Indonesia. Jakarta: Yayasan Obor Indonesia.

Husny, Tengku H.M. Lah. 1978. Lintasan Sejarah Peradaban Sumatra Timur 1612-1950, Jakarta: Depdikbud.

Kahin, Audrey. 1985. Regional Dinamics of Indonesian Revolution: Unity from Diversity. Hawaii: University of Hawaii.

Kartodirdjo, Sartono dan Djoko Suryo. 1991. Sejarah Perkebunan di Indonesia: Kajian Sosial-Ekonomi. Yogyakarta: Aditya Media

Mededeeling van het Oostkust van Sumatra Instituut, No. 26.

Meuraxa, Dada. Sejarah Kebudayaan Suku-suku di Sumatera Utara. Medan: Penerbit Sastrawan.

Paulus, J. 1917. Encyclopedie van Nederlandsch Indie. Leiden: EJ Brill. 
Pelzer, Karl J. 1985. Toean Keboen dan Petani: Politik Kolonial dan Perjuangan Agraria. Jakarta: Penerbit Sinar Harapan.

Reid, Anthony. 1987. Perjuangan Rakyat: Revolusi dan Hancurnya Kerajaan di Sumatera Utara. Jakarta: Sinar Harapan.

. 2012. Sumatera: Revolusi dan Elite Tradisional. Jakarta:

Komunitas Bambu.

(ed). 2010. Sumatera Tempo Doeloe: Dari Marco Polo sampai Tan

Malaka. Jakarta: Komunitas Bambu.

Rothe, Cecil. 1949. Arbeid in de Landbouw: De Landbouw in de Indische Archipel, Vol. I. Den Haag.

Said, Mohammad. 1977. Suatu Zaman Gelap di Deli: Koeli Kontrak Tempo Doeloe dengan Derita dan Kemarahannya. Medan: Waspada.

Sairi, Sjafri. 1997. "Kebijaksanaan Perburuhan di Perkebunan Sumatera Timur Pada Masa Kolonial”, Jurnal Antropologi Indonesia, No. 52, Tahun 1997.

Sinar, Tengku Lukman. 1994. "Sejarah Perkebunan Sumatera Timur Abad ke-19 dan Dampak Sosial-Ekonominya," Makalah Musyawarah Kerja Nasional Sejarah XII, Medan, 12-15 Juli 1994.

Stoler, Ann Laura. 2005. Kapitalisme dan Konfrontasi di Sabuk Perkebunan Sumatera, 1870-1979. Jakarta: Karsa.

Suri Suroto. 1984. "Gerakan Buruh dan Permasalahannya, dalam Prisma, No. 11, Tahun 1984.

Suprayitno. 2001. Mencoba (Lagi) Menjadi Indonesia. Yogyakarta: Yayasan untuk Indonesia.

Suwirta, Andi. 2002. "Buruh Perkebunan di Sumatera Timur: Sebuah Tinjauan Sejarah", dalam Historia Jurnal Pendidikan Sejarah, No. 5, Vol. III, Juni 2002.

Pelly, Usman, Rata. R, dan Soenyata Kartadarmadja. 1984. Sejarah Sosial Daerah Sumatra Utara Kotamadya Medan. Jakarta: Depdikbud 
Wie, Thee Kian. 1977. Plantation Agriculture and Export Growth: an Economic History of East Sumatra 1863-1942. Jakarta: Lembaga Ekonomi dan Kemasyarakatan Nasional.

Winckel, L. J. et. al. 1934. Gemeente Medan 1909-1934. Medan: Tanpa Penerbit. 
